\title{
A troglobitic cryptopid centipede (Chilopoda: Scolopendromorpha) from western Queensland
}

\author{
Gregory D. Edgecombe \\ Australian Museum, 6 College Street, Sydney, NSW 2010, Australia
}

\begin{abstract}
Cryptops (Trigonocryptops) camoowealensis sp. nov. from Five O'Clock cave in the Camooweal district of Queensland, is the second troglobitic species of the subgenus Trigonocryptops to be described from Australia. The new species is less troglomorphic than is a recently described congener from caves in the Nullarbor Region of Western Australia.
\end{abstract}

\section{INTRODUCTION}

The scolopendromorph Cryptops Leach, 1815, is one of the most diverse centipede genera, with 153 named species (Lewis 2002). Among these, troglomorphic species include members of the subgenera Cryptops Leach, 1815, and Trigonocryptops Verhoeff, 1906 (see Edgecombe 2005 and Lewis 2005 for discussion of subgenera of Cryptops and diagnostic characters of Trigonocryptops). Troglomorphic species of Cryptops have been described from caves in Europe, the Canary Islands, Cuba, and Western Australia. The latter record is based on the highly troglomorphic C. (Trigonocryptops) roeplainsensis Edgecombe, 2005, which occurs in caves in the Nullarbor Region. This troglomorph was the first Australian species to be referred to $C$. (Trigonocryptops), which is otherwise known from Spain, North Africa, tropical West, Central and East Africa, Peru, Brazil, Cuba, India, Indonesia, and New Caledonia. Additional records of $C$. (Trigonocryptops) in Australia, as well as occurrence in New Zealand, Fiji and the Solomon Islands, were provided by the reassignment of C. spinipes Pocock, 1891, to that subgenus (Edgecombe 2005).

A new troglobitic species of Cryptops (Trigonocryptops) is described herein from the Camooweal area of western Queensland (Figure 1). Cryptops (Trigonocryptops) camoowealensis sp. nov. occurs in the deep zone of the Five O'Clock cave, Camooweal Caves National Park, $24 \mathrm{~km}$ south of the town of Camooweal. The Camooweal caves are part of the extensive Barkley Karst Region, developed in the Cambrian Camooweal Dolomite Five O'Clock cave (C-36 of Matthews 1985) has a length of $800 \mathrm{~m}+/-10 \mathrm{~m}$, and is dry with connections to intermittent standing water.

Drawings were prepared with a camera lucida attachment to a Leica MZ12. Morphological terminology follows recommendations by Lewis et al. (2005).

\section{SYSTEMATICS}

Family Cryptopidae KohIrausch, 1881

Subfamily Cryptopinae Kohlrausch, 1881

Genus Cryptops Leach, 1815

Type species

Scolopendra hortensis Donovan, 1810, by monotypy.

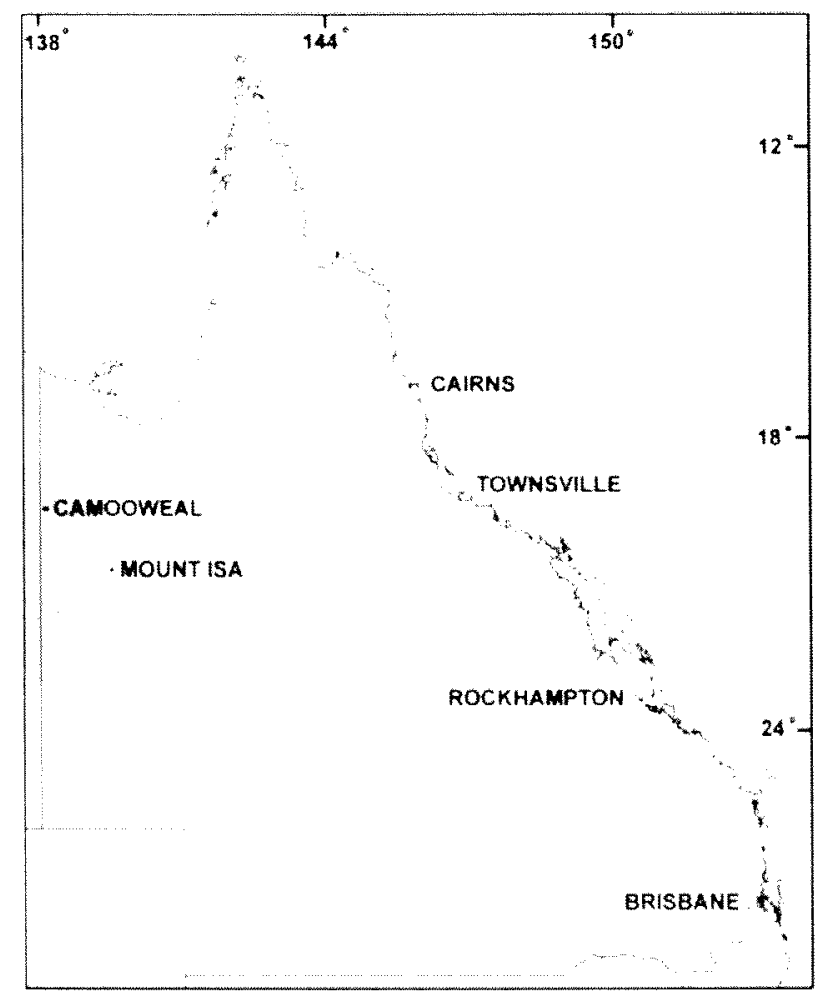

Figure 1 Location of Camooweal, northwestern Queensland. Barkley Karst Region indicated by shading. 
Subgenus Trigonocryptops Verhoeff, 1906

\section{Type species}

Cryptops gigas Kraepelin, 1903, by subsequent designation of Attems (1930).

\section{Cryptops (Trigonocryptops) camoowealensis sp. nov. \\ Figures $2-4$}

\section{Material examined}

\section{Holotype}

Australia: Queensland: Camooweal area, c. $20^{\circ} 05^{\prime} \mathrm{S} 138^{\circ} 10^{\prime} \mathrm{E}$, Five $\mathrm{O}^{\prime}$ Clock Cave, WAM survey BES:6807, 1995, deep zone of cave (WAM T60508, male: Figures 2-4).

\section{Diagnosis}

A Trigonocryptops species with antenna extending back to tergite 6; complete paramedian sutures on head plate and tergites 1-20; complete oblique sutures on tergites 2-7; sternites $2-4$ with anterior transverse suture that curves forwards near lateral margin, anterior longitudinal median suture running to anterior transverse suture; ultimate leg with distal spinose process on anterior side of femur and tibia; $10 / 10$ saw teeth on tibia, $5 / 3$ on tarsus.

\section{Description}

Length (anterior margin of head plate to posterior margin of telson) $37.7 \mathrm{~mm}$. Head plate $1.6 \mathrm{~mm}$ long, antenna $9 \mathrm{~mm}$ long.

Head and tergite 1 pale orange; tergites and sternites 2 and 3 grading to yellow, remainder of trunk (including legs) yellow.

Head plate overlaps tergite 1 ; length and width of head plate nearly equal, posterior corners rounded, sides weakly convex outwards for much of their length, anterior apex indented; paramedian sutures diverging anteriorly on head plate (Figure 2), strongly directed outwards near their anterior termination; head punctate, with relatively sparse, scattered setae.

Antenna composed of 17 articles; basal article stout, articles then gradually increasing in length to a maximum along articles $5-10$, then gradually shortening along articles 11-15; last three articles each about equally long; longest articles 3-3.5 times longer than their maximum width. Article 1 bearing strong, lanceolate setae of varied length (Figure 3E), these strong setae progressively less abundant on articles 2-5; short setae moderately abundant on articles 2-5; from article 6 or 7 , short, fine setae form a fur-like covering, with long setae confined to an irregular whorl around proximal end of each article.

Anterior setose area on clypeus diamond shaped, widest at about $1 / 4$ of its length (Figure 3E), bearing two longer setae and a minute posteromedian seta, flanked by a long seta just outside its widest point. Pair of posteriorly diverging sutures arises from posterior apex of the setose area, terminating at about half distance to labrum, three short setae between these sutures. Band of 11 slender moderately long prelabral setae. Labrum with shallow incision against rounded sclerotised bulge in sidepiece, not strongly tridentate.

Maxillipede with anterior edge of coxosternum convex on each side, bearing a row of six marginal setae (Figure 3C). Coxosternum bearing only a few pairs of moderately long setae, concentrated anteriorly, sparse short setae. Trochanteroprefemur scattered with long to short, fine setae (Figure 3B); band of seven mostly longer setae along inner margin. Single band of setae of varied length on each of femur and tibia. Tarsungulum articulated with trochanteroprefemur along wide hinge.

Apical claw of second maxilla with slender hook distally, lacking a flange along its inner edge. Dorsal brush dense, running along distal threequarters of article 3.

Tergite 1 with complete anterior transverse suture; parallel paramedian sutures; posterolateral sutures gently curved forwards, intersecting posterior margin at their union with paramedian sutures (Figure 2). Lateral longitudinal sutures on tergites 1-19, becoming submarginal by about

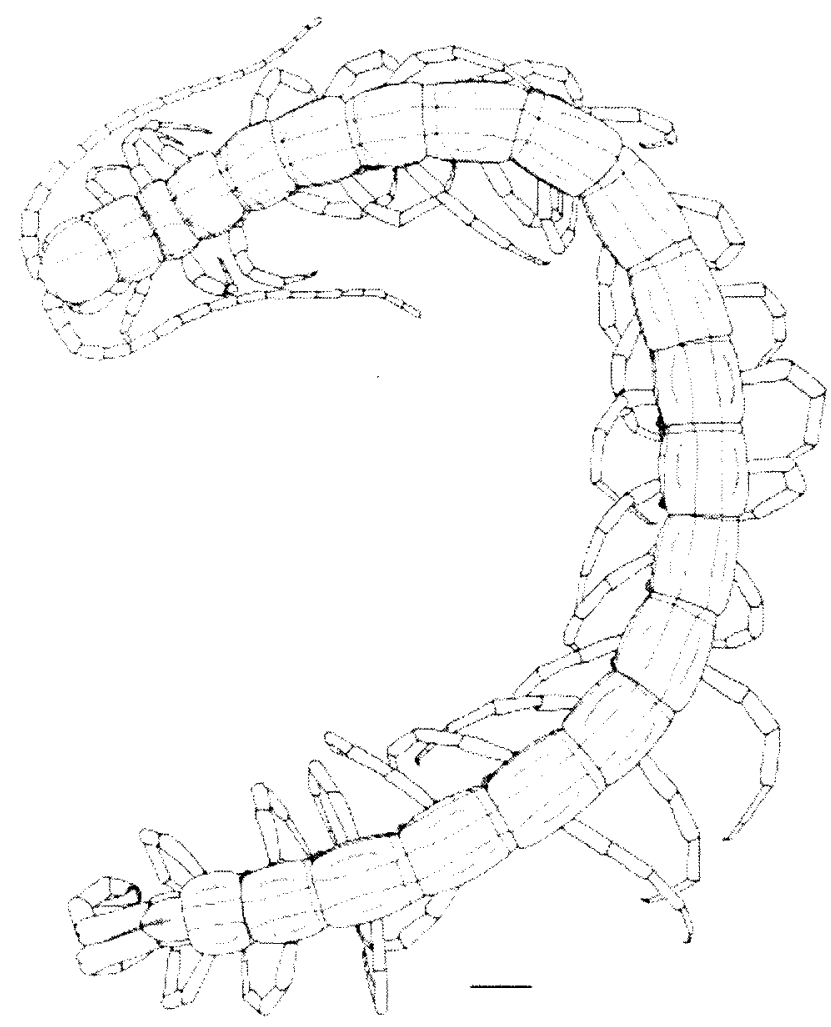

Figure 2 Cryptops (Trigonocryptops) camoowealensis sp. nov. Holotype, WAM T60508. Habitus, scale $1 \mathrm{~mm}$. 

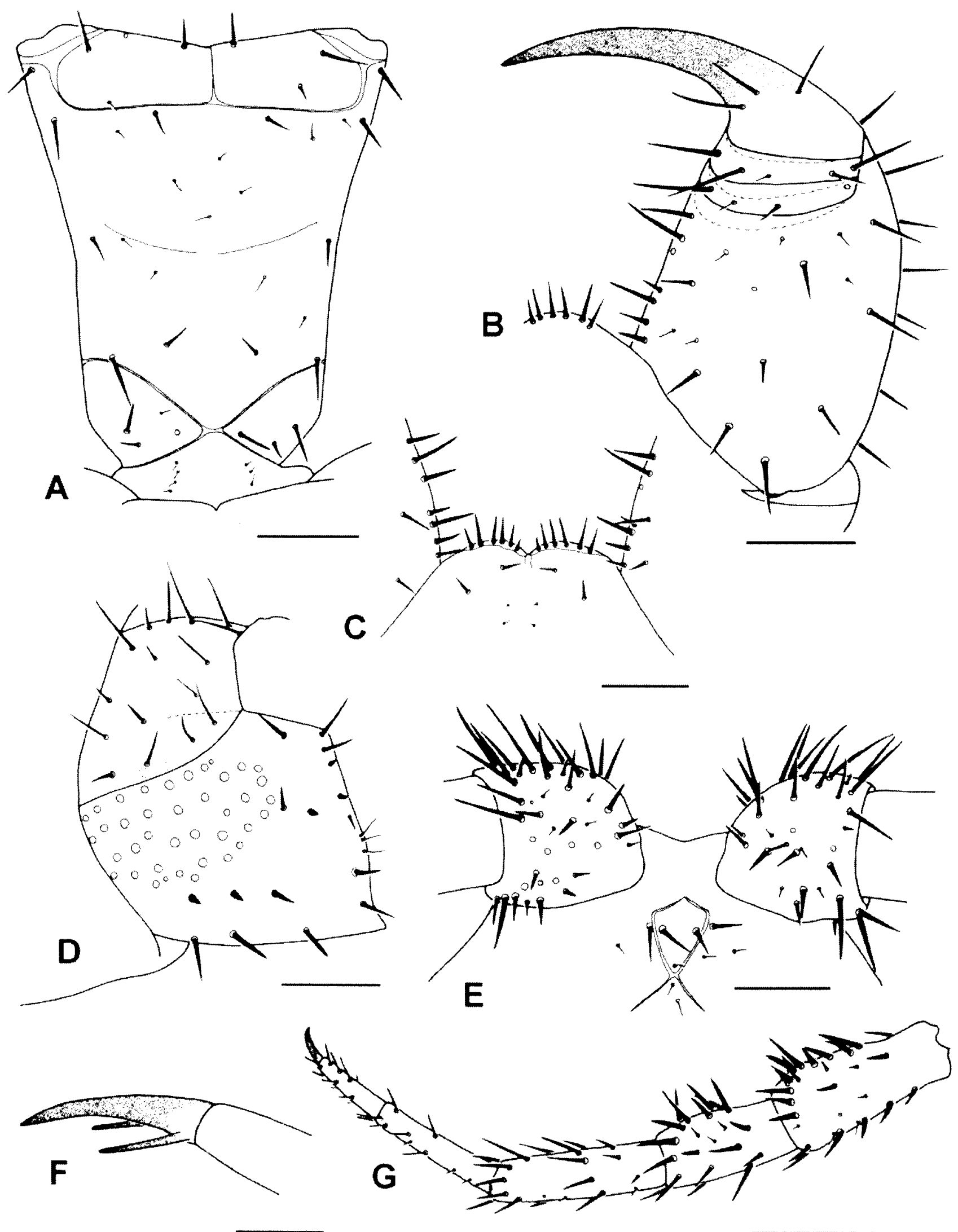

Figure 3 Cryptops (Trigonocryptops) camoowealensis sp. nov. Holotype, WAM T60508. A, sternite 4. B, forcipule. C, margin of maxillipede coxosternum. D, ventrolateral view of sternite and coxopleuron of segment 21 . E, both basal antennal segments and anterior setose area on clypeus. F, anterior view of pretarsus of $\operatorname{leg} 9.6, \operatorname{leg} 1$, posterior side. Scale bars $0.25 \mathrm{~mm}$ except F, $0.1 \mathrm{~mm}$, and $\mathrm{G}, 0.5 \mathrm{~mm}$. 
tergite 6. Complete oblique sutures on tergites 2-7; incomplete oblique sutures on tergite 8 . Lateral region delimited by lateral longitudinal sutures cut by two sutures, one representing the distal part of the oblique sutures on tergites $2-7$ but maintaining the same position even when oblique sutures are incomplete or absent (tergites 8-19). Paramedian sutures converging anteriorly on tergite 2, parallel along much of their length on tergites 3-20 but with weak divergence in their anterior part and more marked divergence in their posterior part; paramedian sutures weakly convergent on pretergite 1, parallel on pretergites $2-4$, divergent on pretergites 5-20. Shallow crescentic sulci on tergites 4-20. Anterior trunk tergites with just a few pairs of short and moderately long setae; mostly symmetrically-paired setae more numerous on posterior tergites. Tergite 21 slightly longer than wide, posterior margin with rounded apex; shallow longitudinal median depression along posterior two-thirds of tergite.

Sternites 2-4 with anterior region bounded by transverse suture that curves forwards near lateral margin of sternum (Figure 3A) and is bisected medially by a longitudinal suture; small transversely elongate sclerite isolated at anterolateral corner of sternite; longitudinal median suture and curved lateral part of transverse suture distinct on sternites 5-7. Sternites 2-19 with curved transverse sulcus; shallow longitudinal sulcus on sternites 4-19, their intersection forming a large depression. Sternites sparsely scattered with moderately long, symmetrically-paired setae, mostly concentrated near margins; inner part of sternites with numerous short, fine setae; setae coarsest on sternite 1 . Anterior branch of trigonal sutures complete on sternites 3-6. Endosternite with two subparallel rows of short setae (Figure $3 \mathrm{~A}$ ).

Spiracles elongate elliptical.

Legs relatively long and thin, e.g., leg 10 with prefemur $0.9 \mathrm{~mm}$ long, femur $0.8 \mathrm{~mm}$, tibia $1.0 \mathrm{~mm}$, tarsus $10.9 \mathrm{~mm}$, tarsus $20.35 \mathrm{~mm}$ compared to tergal width of $1.55 \mathrm{~mm}$. All tarsi strongly bipartite. Leg 1 (Figure 3G) with robust lanceolate to subspiniform setae on all surfaces of prefemur and femur, slightly more slender on tibia, considerably more slender on tarsus; from leg 2, lanceolate setae on prefemur to tibia more slender and of more even thickness on each podomere; tarsal setae shorter, slender. Leg 20 prefemur and femur about equally long; tarsus 20.54 times as long as tarsus 1 (Figure $4 \mathrm{~F}$ ); lacking dense tufts of setae ventrally. Ultimate leg: prefemur $2.1 \mathrm{~mm}$ long, femur $1.8 \mathrm{~mm}$, tibia 1.3 $\mathrm{mm}$, tarsus $10.9 \mathrm{~mm}$, tarsus $21.4 \mathrm{~mm}$; prefemur and femur 4.5 and 4.7 times longer, respectively, than their maximal widths at distal ends (Figure $4 \mathrm{E}$ ); distal spinose process on anterior side of femur and tibia, lacking on posterior side; robust lanceolate setae on anterior, posterior and ventral sides of prefemur, mostly slender setae on dorsal side; robust lanceolate setae confined to posterior and ventral sides of femur, anterior and dorsal sides with slender setae; tibial and tarsal setae exclusively slender; 10/10 saw teeth on tibia (Figure 4A), 5/3 on tarsus 1 (Figure $4 \mathrm{~B}$ ); inner margin of tarsus 2 a ridge. Pair of gently divergent accessory spurs half length of pretarsus on legs 1-20 (Figure 3F); anterior accessory spur slightly longer than posterior spur; accessory spurs lacking on ultimate leg.

Sternite 21 with sides weakly convex and converging posteriorly; posterior corners rounded, hind edge approximately transverse. Coxopleural pore field elliptical, terminating at a distance from posterior margin of coxopleuron about half the height of the pore field, with up to 40 pores (Figure $3 \mathrm{D})$, no setae amidst the pores. Row of three or four robust lanceolate setae above pore field, two lanceolate setae behind pore field. Posterior margin of coxopleuron bearing seven strong setae and a few fine setae.

\section{DISCUSSION}

Membership in Cryptops (Trigonocryptops) is indicated by the trigonal sutures on several anterior sternites and a projection at the anterolateral corner of the endosternite (Figure 3A), an anterior setose area on the clypeus delimited by sutures (Figure $3 \mathrm{E}$ ), the head overlying tergite 1 and a transverse suture on tergite 1 (Figure 2), distal spinose projections on the femur and tibia of the ultimate leg (Figures 4C, D), and bipartite tarsi on all legs (Figure $3 G$ ).

The new species does not exhibit the extreme troglomorphic characters of Cryptops (Trigonocryptops) roeplainsensis Edgecombe, 2005, or C. (T.) troglobius Matic et al., 1977, having only moderate elongation of the antennal articles, legs and tergites compared to epigean species of $C$. (Trigonocryptops). In addition to its lesser degree of troglomorphy (i.e., shorter antennae and legs, fewer saw teeth on the ultimate leg), the new species is distinguished from $C$. (T.) roeplainsensis by its continuous paramedian sutures on tergites $1-$ 3 , lateral longitudinal sutures on tergite 1 ; much sparser setation on the trunk sternites, maxillipede coxosternum, and forcipule; fewer fine setae on the proximal parts of legs 20 and 21; single (versus paired) distal spinose processes on the femur and tibia of leg 21; and far fewer coxopleural pores on $\operatorname{leg} 21$.

Cryptops (Trigonocryptops) camoowealensis and C. (T.) spinipes Pocock, 1891, the latter known from New South Wales (Sydney and the Blue Mountains: Chamberlin 1920), Queensland (Blackal Ranges and Atherton Tablelands: Kraeplin 1916), Fiji, the Solomon Islands (Chamberlin 1920) and New Zealand (Archey 1924), share continuous 

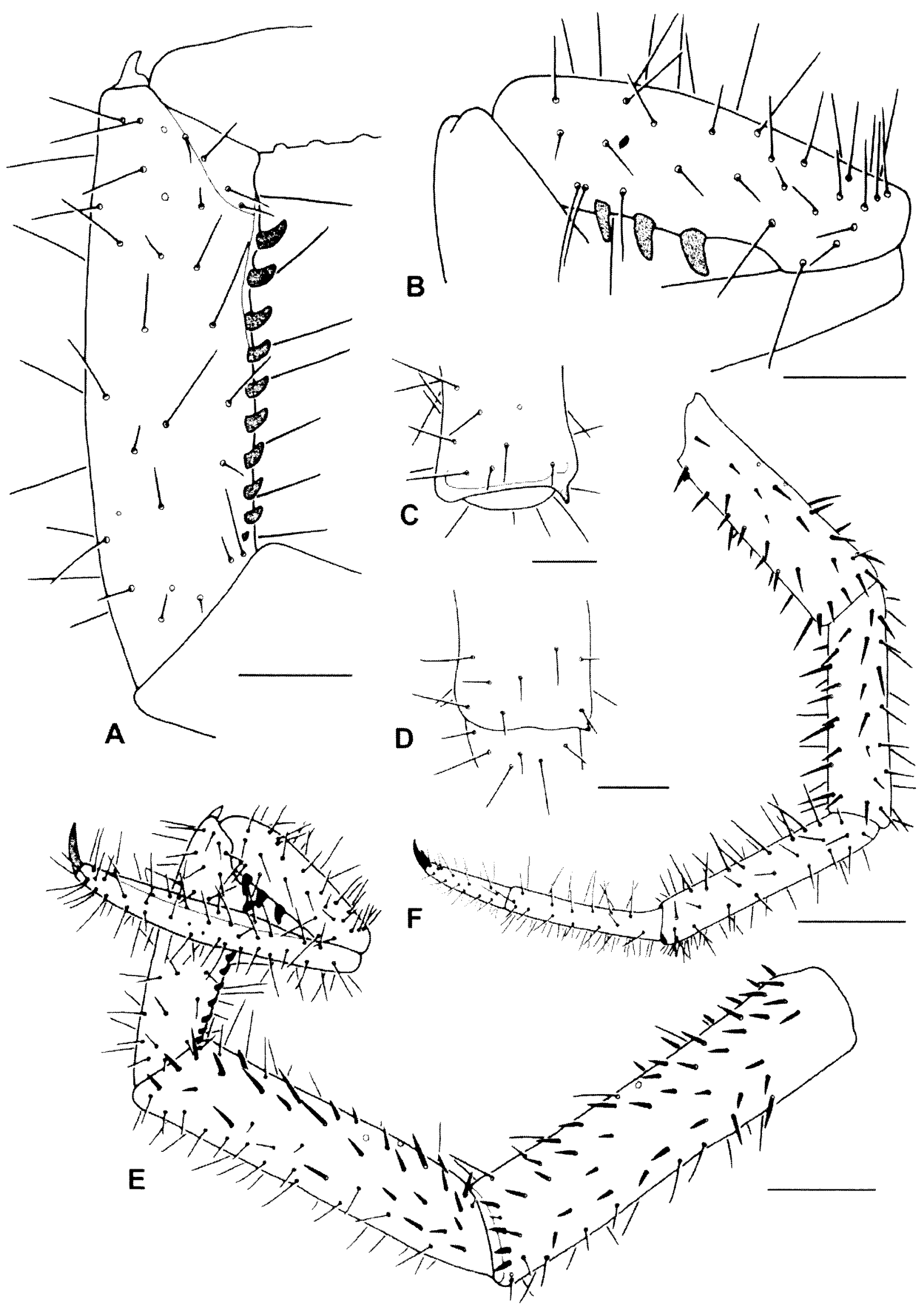

Figure 4 Cryptops (Trigonocryptops) camoowealensis sp. nov. Holotype, WAM T60508. A-E, leg 21. A, tibia. B, tarsus 1. C, D, distal end of tibia and femur, dorsal views. $E$, posterior view of leg. F, leg 20 posterior view. Scale bars $0.25 \mathrm{~mm}$ except $\mathrm{E}, \mathrm{F}, 0.5 \mathrm{~mm}$. 
paramedian sutures on the head plate and robust lanceolate and subspiniform setae on the legs. The new species is most readily distinguished from $C$. (T.) spinipes by its tendency towards troglomorphy (longer legs, e.g., the ultimate leg having a markedly longer prefemur, femur and tibia; longer antennal articles), as well as by its predominantly yellow rather than orange pigment, and having complete, parallel paramedian sutures on tergite 1 and oblique sutures on tergite 2 .

Among non-Australian species, C. (T.) loveridgei Lawrence, $1953[=C$. (T.) bokumensis Kraus, 1958, fide Lewis, 2005] from Tanzania and the Democratic Republic of Congo, is similar to $C$. (T.) camoowealensis in most respects, e.g., the segmental distribution of paramedian sutures, setation of the maxillipede coxopleural margin, presence of posteriorly-diverging sutures behind the anterior setose area on the clypeus, and comparable proportions and dentition of the ultimate leg. The specific distinction of $C$. (T.) camoowealensis is indicated by having curved posterolateral sutures on tergite 1, complete oblique sutures on tergites 2-7 (versus 2 to 4 or 5), a less extensive series of trigonal sutures on the sternum, presence of anterior transverse and longitudinal median sutures on sternites $2-4$, and less developed distal spinose processes on the ultimate leg (lacking a process on the prefemur, single rather than paired processes on the tibia).

\section{ACKNOWLEDGEMENTS}

I thank Suzanne Bullock for illustrations. The holotype was made available courtesy of Mark Harvey and Julianne Waldock (Western Australian Museum). John Lewis and Alessandro Minelli made useful suggestions for improving the manuscript.

\section{REFERENCES}

Archey, G. (1924). The genus Cryptops (Chilopoda) in New Zealand. Record of the Canterbury Museum 2: 203-220.

Attems, C. (1930). Myriapoda 2. Scolopendromorpha. In F.E. Schulze and W. Kükenthal (eds), Das Tierreich 54. Walter de Gruyter and Co., Berlin and Leipzig.

Edgecombe, G.D. (2005). A troglomorphic species of the centipede Cryptops (Trigonocryptops) (Chilopoda: Scolopendromorpha) from Western Australia. Records of the Western Australian Museum 22: 315323.
Kraepelin, K. (1916). Results of Dr E. Mjöberg's Swedish Scientific Expeditions to Australia 1910-1913. 4, Scolopendriden und Skorpione. Arkiv för Zoologi 10: $1-43$.

Kraus, O. (1958). Myriapoda (Chilopoda, Diplopoda). Parc National de I'Upemba, I. Mission G. F. de Witte en collaboration avec $W$. Adam, A. Janssens, L. van Meel et $R$. Verheyen (1946-1949) 54: 4-67.

Lawrence, R.F. (1953). Zoological results of a fifth expedition to East Africa V Chilopoda (Myriopoda). Bulletin of the Museum of Comparative Zoology at Harvard College 110: 409-423.

Leach, W.E. (1815). A tabular view of the external characters of four classes of animals which Linné arranged under Insecta; with the distribution of the genera composing three of these classes into orders, etc. and descriptions of several new genera and species. Transactions of the Linnean Society of London, Series 1, 11: 306-400.

Lewis, J.G.E. (2002). The scolopendromorph centipedes of Mauritius and Rodrigues and their adjacent islets (Chilopoda: Scolopendromorpha). Journal of Natural History 36: 79-106.

Lewis, J.G.E. (2005). A reassessment of Cryptops loveridgei Lawrence, with observations on the subgenus Trigonocryptops Verhoeff and Paratrigonocryptops Demange (Chilopoda, Scolopendromorpha). African Invertebrates 46: 115124.

Lewis, J.G.E., Edgecombe, G.D. and Shelley, R.M. (2005). A proposed standardised terminology for the external taxonomic characters of the Scolopendromorpha (Chilopoda). Fragmenta Faunistica 48: 1-8.

Matic, Z., Negrea, S. and Fundora Martinez., C. (1977). Recherches sur les Chilopodes hypogés de Cuba (II). Résultats des expéditions biospéologiques cubanoroumaines à Cuba 2: 277-301.

Matthews, P.G. (ed.) (1985). Australian Karst Index 1985. Australian Speleological Federation Inc.

Pocock, R.I. (1891). Descriptions of some new species of Chilopoda. Annals and Magazine of Natural History, Series 6, 8: 152-164.

Verhoeff, K.W. (1906).Vergleichend morphologische Studie über die coxopleuralen Körperteile der Chilopoden, mit besonderer Berücksichtigung der Scolopendromorpha, ein Beitrag zur Anatomie und Systematik derselben nebst physiologischen Mitteilungen und Ausblicken auf die Insekten. Nova Acta Academiae Caesareae Leopoldino-Carolinae Germanicum Naturae Curiosorum 86: 349-501.

Manuscript reccived 17 October 2005; accepted 10 May 2006 